\title{
Phytochemical and pharmacological activities of methanol extract of Artemisia vulgaris L. leaves
}

\author{
Nurpen Meitei Thangjam, Jasmina Taijong and Awadhesh Kumar ${ }^{*}$
}

\begin{abstract}
Background: Artemisia vulgaris commonly known as "mugwort" is a very important medicinal plant which is used widely for the treatment of various ailments traditionally. The present studies aimed to conduct preliminary phytochemical screening and evaluate antioxidants and analgesic activities of leaves extract.

Results: Phytochemical screening showed the presence of saponins, glycosides, flavanoids, protein, triterpenoids in leaves extract. In DPPH, percentage inhibition of the scavenging activity (68.06\%) by the extract in comparison with ascorbic acid (93.53\%) at $60 \mathrm{\mu g} / \mathrm{ml}$ while in reducing power assay, the result shown the reducing power increases with the increase of concentration as $(0.13 \pm 0.02),(0.27 \pm 0.03),(0.42 \pm 0.03),(0.62 \pm 0.05),(0.79 \pm 0.02),(0.95 \pm 0.05)$ at concentration of 5, 10, 15, 30,60 and $100 \mathrm{\mu g} / \mathrm{ml}$ respectively. The evaluation of analgesic activities revealed that at the dose of 200 and $400 \mathrm{mg} / \mathrm{kg}$ of the extract showed significantly inhibited the writhing response induced by acetic acid by $8.60 \%$ and $32.03 \%$ comparatively with indomethacin at a dose of $10 \mathrm{mg} / \mathrm{kg} \mathrm{b}$. wt. exhibited $56.87 \%$ inhibition. Whereas, in the tail immersion methods, at the dose of $400 \mathrm{mg} / \mathrm{kg}$ b. wt. was showed higher deflexion value as $3.40 \pm 0.300$, while $200 \mathrm{mg} / \mathrm{kg}$ b. wt. was resulted at $2.90 \pm 0.200$ value in dose dependent manner at the maximum time of the studies (60 min). Comparatively, the reference drug indomethacin at dose $10 \mathrm{mg} / \mathrm{kg} \mathrm{b}$. wt. has shown the highest deflexion value $(5.134 \pm 0.351)$.

Conclusion: This finding concludes that the methanolic leaves extract has a potent antioxidants and analgesic activities and it could be attributed to the presence of flavonoids, triterpenoids, saponin, glycosides and proteins. A further study is required to find out the novel bioactive compound of Artemisia vulgaris $\mathrm{L}$. which can lead more effective in various biological activities.
\end{abstract}

Keywords: Antioxidants, Analgesic, Artemisia vulgaris, DPPH, Phytochemicals, Reducing power

\section{Background}

Aromatics and Medicinal plants are one of the main significant sources of phytochemical constituent called secondary metabolites, which have been used widely in most of the pharmaceutical companies [1]. The World Health Organization (WHO) conducted a survey and reported that the total world's populations of around $80 \%$ were depends on traditional knowledge of medicines,

\footnotetext{
* Correspondence: kumarawadhesh9@gmail.com

Department of Horticulture Aromatic \& Medicinal Plants, School of Earth

Sciences \& Natural Resource Management, Mizoram University, Aizawl, Mizoram 796009, India
}

\section{Springer Open}

especially the medicinal plants for supporting their healthcare [2, 3]. In the plant kingdom, the genus Artemisia consists of small herbs and shrubs, found in northern temperate regions of South Asia, North America and European countries [4]. Artemisia vulgaris which is commonly known as "mugwort" is a perennial shrubby aromatic plant found wildly throughout the hills of India and it has a very unique medicinal values and it was recorded in the ayurvedic traditional system of medicine; the presence of phytoconstituent (terpenoids and sesquiterpene lactones) hold strong aromatic properties and bitter tastes makes discourage to the
(0) The Author(s). 2020 Open Access This article is licensed under a Creative Commons Attribution 4.0 International License, which permits use, sharing, adaptation, distribution and reproduction in any medium or format, as long as you give appropriate credit to the original author(s) and the source, provide a link to the Creative Commons licence, and indicate if changes were made. The images or other third party material in this article are included in the article's Creative Commons licence, unless indicated otherwise in a credit line to the material. If material is not included in the article's Creative Commons licence and your intended use is not permitted by statutory regulation or exceeds the permitted use, you will need to obtain permission directly from the copyright holder. To view a copy of this licence, visit http://creativecommons.org/licenses/by/4.0/. 
herbivorous and acts as a shield or defence mechanism and acts as a good larvicide like kerosene with insecticidal property too. Likewise, the plants has acknowledged with the high contain of the important compounds like flavonoids and terpenoids which used as a flavoring agents as well as highly antioxidant properties with several health benefits [5-9].

Since ancient period, the genus Artemisia from the family Asteraceae having more than 400 known species were commonly used as an antimalarial agent and as traditional medicine around the world because of its unique medicinal properties, and it also included in traditional Anatolian medicine system $[10,11]$. Whereas, it was used in Korean traditional medicine for the treatments of various ailments like convulsions, fever, malaria and later polyphenolic chemistry was also investigated [12]. The plant extracts of Artemisia have been found to be rich in phenolic and flavanoids contents and were used for the cure of several diseases with sufficient scientific proof supports for its medicinal property as antidiabetic, anti-epileptic, antihelmintic, antimalarial, anti-microbial, antinociceptive, anti-oxidants anti-hysteric, diuretic, digestive and stimulant [13-16]. Additionally, there was a report that the Artemisia vulagris plant contains the important phytoconstituent such as oils, phenols, saponins, sesquiterpenoids as well as tannins, and has been evaluated for analgesic and anti-inflammatory activities [17].

Analgesic drugs mechanism is to interrupt nociceptive pathways that transmit impulses to be interpreted as pain in the central nervous system [18]. The pain relief therapies were progressing with the application of synthetic compound with the development of the science, the researcher is looking to target the compound isolated mostly from the plant resources to avoid the adverse side effects [19]. Along with analgesic effect, there is a believe that most of the medicinal plants possess antioxidant properties which can able to inhibit the free radicals from our human body and to protect from various harmful diseases caused by the free radicals [20]. The scientific investigations on the selected herbs were necessary in order to accomplish their antioxidant and analgesic properties. An increasing number of research work and evaluation have been done to find antioxidative drugs, which not only extend the shelf life of food products but also contribute as radical scavengers in living organisms. Therefore, the present study was carried out on Artemisia vulgaris L. to contribute for the development of modern analgesic and antioxidants drugs from the naturally occurring secondary metabolites derived from plants.

\section{Methods}

\section{Collection and extraction of plant material}

The fresh aerial parts of Artemisia vulgaris were collected from Mizoram University Campus, Tanhril. These were then cleaned and removed the stalks, branches and stems. Only the leaves were taken and shade dried, and further the dried leaves were chopped and grinded with the help of an electronic grinder. The powder was extracted with $99.8 \%$ methanol by cold maceration technique. The liquid extract obtained was filtered by using Whatman filter paper 1 and allowed to evaporate in a rotary evaporator so as to get the plant extract in the crude form. This was collected and stored properly in refrigerator at $4{ }^{\circ} \mathrm{C}$ for further used.

\section{Preliminary phytochemical screening}

The detection of phytoconstituent present in the methanolic extract of $A$. vulgaris (MEAV) leaves was carried out by standard methods.

\section{Test for proteins (Xanthoproteic test)}

In $2 \mathrm{ml}$ of extract add $2 \mathrm{ml}$ of concentrated $\mathrm{HNO}_{3}$ observation of orange colour indicates the presence of proteins [21].

\section{Test for carbohydrates (Benedict's test)}

In $2 \mathrm{ml}$ of extract add $2 \mathrm{ml}$ of Benedict's reagent and boiled. Formation of orange red precipitate indicates the presence of carbohydrates [21].

\section{Test for alkaloids (Mayer's test)}

In $2 \mathrm{ml}$ of the extract, drops of Mayer's reagent were slowly added by the side of the test tube, formation of a white or creamy precipitate indicates the presence of alkaloids [22].

\section{Test for Flavanoids (alkaline reagent test)}

$2 \mathrm{ml}$ of $2 \%$ sodium hydroxide solution was added to $2 \mathrm{ml}$ of the extract. Appearance of yellow colour precipitation indicates the presence of flavonoids [22].

\section{Test for Triterpenoids (Salkowski's test)}

In $2 \mathrm{ml}$ of extract add $1 \mathrm{ml}$ of chloroform followed by a few drops of concentrated $\mathrm{H}_{2} \mathrm{SO}_{4}$ on the side of the test tube and shaken well, formation of yellow colour at the lower layered indicates the presence of triterpenoids [22].

\section{Test for Saponins (frothing test)}

$2 \mathrm{ml}$ of extract was diluted with $10 \mathrm{ml}$ of distilled water in a test tube and shaken for 5 mins, observation of stable foam indicates the presence of saponins [23].

\section{Test for tannins (ferric chloride test)}

$2 \mathrm{ml}$ of the extract was mixed with few drops of $10 \%$ ferric chloride solution, the change of colour into dark blue or green indicates the presence of gallic tannins and catechol tannins [23]. 


\section{Test for glycosides (Keller-Kilani test)}

A mixture of $4 \mathrm{ml}$ of glacial acetic acid and 1 drop of $2.0 \% \mathrm{FeCl}_{3}$ was added to $10 \mathrm{ml}$ of the extract followed by the addition of $1 \mathrm{ml}$ of concentrated $\mathrm{H}_{2} \mathrm{SO}_{4}$. Formation of brown ring between the layers indicates the presence of cardiac glycosides [24].

\section{In-vitro antioxidant assay}

\section{DDPH free radical scavenging activity}

Radical scavenging activity of methanolic extract of $A$. vulgaris (MEAV) leaves was determined by Calorimetric assay using 2,2-diphenyl-1-picrylhydrazyl (DPPH) as a source of free radical according to the method of Blois with a slight modification $[25,26]$. Stock solutions of MEAV extract were prepared at a concentration of 1 $\mathrm{mg} / \mathrm{ml}$ and for test sample; it was serially diluted to make the concentrations of 10, 20, 30, 40, 50 and $60 \mu \mathrm{g} /$ $\mathrm{ml}$ respectively.

$0.1 \mathrm{mM}$ DPPH solution was prepared by dissolving $3.94 \mathrm{mg}$ in $100 \mathrm{ml}$ of methanol and then $1 \mathrm{ml}$ of this solution was mixed with $150 \mu \mathrm{l}$ methanol, which was used as control. The above mentioned concentration of MEAV was taken and mixed with $1 \mathrm{ml}$ DPPH solutions to each test tube. After 15 min of incubation, the absorbance of control and test sample was measured at $516 \mathrm{~nm}$ in UV- visible spectrophotometer and the compound ascorbic acid was used as a reference. The percentage inhibition and $\mathrm{IC}_{50}$ were calculated. The free radical scavenging activity (\% inhibition activity) was calculated using the given equation-

\%inhibition activity $=\frac{\text { Control absorbance }- \text { Sample absorbance }}{\text { Control absorbance }} \times 100$

\section{Reducing power by $\mathrm{FeCl}_{3}$}

Reducing power of MEAV was measured by method of Oyaizu with slight modifications $[27,28]$. Stock solutions of MEAV were prepared at a concentration of $1 \mathrm{mg} / \mathrm{ml}$ and the test sample concentrations as 5, 10, 15, 30, 60 and $100 \mu \mathrm{g} / \mathrm{ml}$ were made by serial dilution.

Here, $2 \mathrm{ml}$ of above concentration were mixed thoroughly with $2.5 \mathrm{ml}$ of phosphate buffer $(\mathrm{pH} 6.6)$ and 2.5 $\mathrm{ml}$ of $1 \%$ potassium ferricyanide solution. These mixtures were warm up in the water bath at a constant temperature of $50{ }^{\circ} \mathrm{C}$ for $20 \mathrm{~min}$ and then allowed for cooling, added $2.5 \mathrm{ml}$ of $10 \%$ trichloroacetic acid to the mixture and centrifuged for $10 \mathrm{~min}$ at $3000 \mathrm{rpm}$. After centrifugation, $2.5 \mathrm{ml}$ of supernatant part was taken and mixed with $2.5 \mathrm{ml}$ of distilled water and $0.5 \mathrm{ml}$ of $0.1 \%$ ferric chloride and incubated for $10 \mathrm{~min}$. Then, absorbance at $700 \mathrm{~nm}$ was measured in spectrophotometer. Control value was also recorded with same procedure without the MEAV. The standard compound Ascorbic acid was used as a reference compound.

\section{Test animals}

The Swiss albinos male mice weighing between 18 and $25 \mathrm{~g}$ obtained from the animal house of department of zoology, Mizoram University were used for testing of the present study. These animals were kept in a wellventilated room at a maintained temperature of $25 \pm 2{ }^{\circ} \mathrm{C}$ with 12:12 h light/dark cycle in polypropylene cages containing sterile locally procured paddy husk as bedding. The animals were fed with commercially available food pellets and water ad libitum till the completion of the experiment. Animals were adapted in the laboratory environment 15 days earlier to initiation of studies.

All the investigation protocols followed in the experiment were revised by the Institutional animal ethical committee and followed accordingly under the guidelines of CPCSEA (2003) [29]. The present research was approved by the Institutional Animal Ethical Committee, Mizoram University, India. (Approval No. MZU-IAEC/ 2018/10).

\section{Acute toxicity test}

The acute toxicity study of the MEAV was carried out for the selection of dose according to the OECD guidelines [30]. The extract was administered orally at increasing doses of 500, 1000 and $2000 \mathrm{mg} / \mathrm{kg}$ and the observation was made for $48 \mathrm{~h}$ for its behavioral changes, any toxicity and mortality. No mortality and other acute toxicity effect were found. Therefore, the doses for the present investigation were selected at 200 and $400 \mathrm{mg} /$ $\mathrm{kg}$ body weight for analgesic evaluation $[15,31]$.

\section{In-vivo analgesic activity}

\section{Acetic acid induced writhing}

The In-vivo analgesic activity was carried out by acetic acid induced writhing method [32]. Swiss albino mice were categorized in 4 groups with 6 animals in each groups and proper marking was done individually as test group I and II, standard group and control group. The test groups were received with MEAV at a dose of 200 and $400 \mathrm{mg} / \mathrm{kg}$ b. wt. respectively. Similarly, indomethacin of dose $10 \mathrm{mg} / \mathrm{kg} \mathrm{b}$. wt. used as a standard drug and normal saline as control were given orally with the help of a gavage $30 \mathrm{~min}$ before the administered of $0.7 \%(\mathrm{v} / \mathrm{v})$ acetic acid $(0.01 \mathrm{ml} / \mathrm{g})$ intraperitoneal injection to induce the writhing. The writhes count (number of abdominal constrictions) were observed and counted for $30 \mathrm{~min}$ for every single animal in each group.

Percentage of protection was expressed using formula:

Percentage of protection $=(\mathrm{A}-\mathrm{B}) / \mathrm{A} \times 100$

Where, $\mathrm{A}=$ No. of writhes in control, $\mathrm{B}=$ No. of writhes in test. 
Table 1 Phytochemical screening of the methanol extract of Artemisia vulgaris

\begin{tabular}{lll}
\hline Sl. No. & Phytoconstitutents & Test results \\
\hline 1 & Proteins (Xanthoproteic test) & Present \\
2 & Carbohydrates (Benedict's test) & Absent \\
3 & Alkaloids (Mayer's test) & Absent \\
4 & Flavanoids & Present \\
5 & Triterpenoids & Present \\
6 & Saponins (frothing test) & Present \\
7 & Tannins & Absent \\
8 & Glycosides (Keller-Kilani test) & Present \\
\hline
\end{tabular}

\section{Tail immersion methods}

Tail immersion methods in mice were employed to detect the analgesic activity $[33,34]$. The experiment was carried out on the basis of observation that the pain relieve drugs was capable of lasting the time taken for the reflex withdrawal of tail by mice when immersed in warm water at a temperature of $55^{\circ} \mathrm{C}$.

According to divided groups, the standard group received the drug indomethacin at the dose $10 \mathrm{mg} / \mathrm{kg} \mathrm{b}$. wt., the test group treated with MEAV at the dose of 200 and $400 \mathrm{mg} / \mathrm{kg}$ b. wt. respectively and normal saline in control were administered orally. After the administration of the test and standard drug, the lower part of the tail was marked up to1-2 cm and dipped into the water bath at $55^{\circ} \mathrm{C}$ temperature. The reaction time of the deflexion of tail by the mice were observed and recorded at $0,10,15,30$ and $60 \mathrm{~min}$ respectively.

\section{Statistical analysis}

The data obtained in in vitro antioxidant activity were expressed as mean \pm standard deviation of mean (SD) and the statistical significance of in-vivo analgesic activity was analyzed by one way analysis of variance (ANOVA) followed by post hoc Duncan multiple comparison tests.

\section{Results}

\section{Phytochemical screening}

The phytochemical screening test of the methanol extract of $A$. vulgaris (MEAV) leaves was presented in Table 1. The Test results showed the presence of saponins, glycosides, flavanoids, protein, triterpenoids.

\section{In-vitro antioxidants activity}

Antioxidant properties of the MEAV was measured using DPPH radical scavenging and reducing power properties. The antioxidant ability of the leaves extract was analysed based on their ability to scavenging free radicals. In present study, the MEAV showed high scavenge activity of DPPH radical, which may attribute to its hydrogen donating ability. The antioxidant activity of both MEAV extract and standard (ascorbic acid) comparatively tested at different concentrations (10, 20, 30, $40,50,60 \mu \mathrm{g} / \mathrm{ml})$. The DPPH radical scavenging properties were found to be concentration dependent shown in Fig. 1. The percentage inhibition of MEAV extract was found in the range of $12.23-68.06 \%$ which was lower than ascorbic acid (14.37-93.53\%). This means the inhibition percentage was also increase with increase in concentration of MEAV. The $\mathrm{IC}_{50}$ value obtained for ascorbic acid and Artemisia vulgaris is 2.9 and 4.3 respectively (Table 2).

In order to confirm the antioxidant activities, the plant extract was further analyzed by reducing power assay. Here, it was observed that the absorbance at $700 \mathrm{~nm}$ was increased with the increase in the concentration of the MEAV which was mainly due to the conversion of ferric to ferrous ions shown in Fig. 2. The absorbance of the MEAV was observed as $0.13 \pm 0.02,0.27 \pm 0.03,0.42 \pm$ $0.03,0.62 \pm 0.05,0.79 \pm 0.02$ and $0.95 \pm 0.05$ in comparison with the standard (ascorbic acid) with $0.18 \pm 0.03$, $0.35 \pm 0.04, \quad 0.53 \pm 0.05, \quad 0.71 \pm 0.01, \quad 0.85 \pm 0.05$ and $1.04 \pm 0.05$ at concentration of $5,10,15,30,60$ and $100 \mu \mathrm{g} / \mathrm{mL}$ respectively (Table 3 ).

\section{In-vivo analgesic activity}

The peripheral analgesic effect of MEAV was evaluated by acetic acid induced writhing test in mice. The

Table 2 Percentage inhibition of methanol extract of $A$. vulgaris leaves and standard (ascorbic acid)

\begin{tabular}{lll}
\hline Concentration & Percentage inhibition (MEAV) & Percentage inhibition (AA) \\
\hline $10 \mu \mathrm{g} / \mathrm{ml}$ & 12.35 & 14.37 \\
$20 \mu \mathrm{g} / \mathrm{ml}$ & 26.94 & 36.23 \\
$30 \mu \mathrm{g} / \mathrm{ml}$ & 35.82 & 56.50 \\
$40 \mu \mathrm{g} / \mathrm{ml}$ & 46.46 & 67.17 \\
$50 \mu \mathrm{g} / \mathrm{ml}$ & 57.16 & 80.75 \\
$60 \mu \mathrm{g} / \mathrm{ml}$ & 68.06 & 93.53 \\
$\mathrm{I} C_{50} \mathrm{\mu g} / \mathrm{ml}$ & 4.3 & 2.9 \\
\hline
\end{tabular}




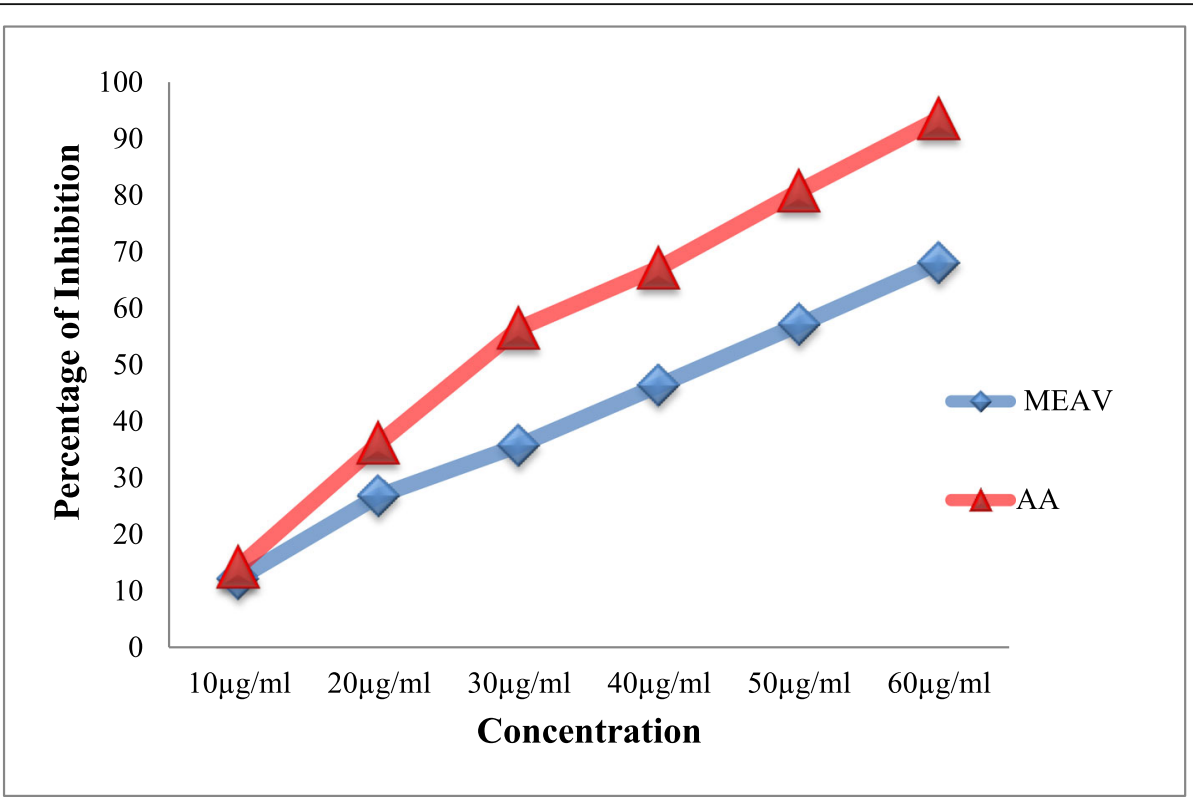

MEAV-Methanol extract, AA-Ascorbic acid

Fig. 1 DPPH scavenging activity (\% inhibition vs concentration) of $A$. vulgaris leaves extract in comparison with ascorbic acid

analgesic effect was tested at selected dose of MEAV at 200 and $400 \mathrm{mg} / \mathrm{kg}$ b. wt. The given doses of MEAV were showed an inhibition effect on the writhing reaction induced by acetic acid in comparison with the standard drug indomethacin. The doses of MEAV at 200 and $400 \mathrm{mg} / \mathrm{kg}$ b.wt. has significantly inhibited the writhing response induced by acetic acid at $8.60 \%$ and $32.03 \%$ respectively whereas indomethacin at a dose of $10 \mathrm{mg} / \mathrm{kg}$ b. wt. exhibited $56.87 \%$ inhibition (Table 4).

This study was accordance with test of tail immersion methods. Here, the control group showed faster tail flicks which increases at different intervals of time. The MEAV exhibited potent analgesic activity at the dose levels of 200 and $400 \mathrm{mg} / \mathrm{kg}$ b. wt. The analgesic activity of higher dose

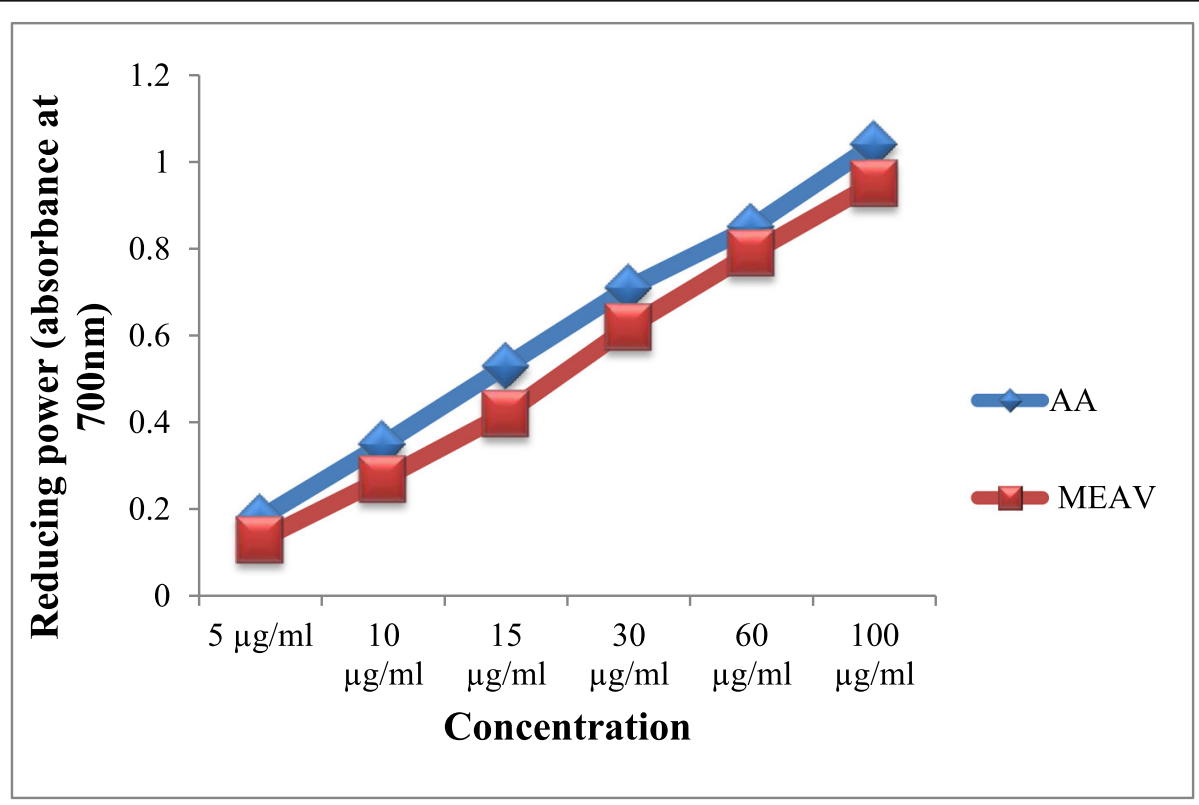

MEAV-Methanol extract, AA-Ascorbic acid

Fig. 2 Reducing power (absorbance vs different concentration) of $A$. vulgaris leaves extract and standard antioxidants 
Table 3 Absorbance at different concentration of methanol extract of $A$. vulgaris leaves and standard ascorbic acid in reducing power

\begin{tabular}{lll}
\hline Concentration & Absorbance of AA (Mean \pm SD) & Absorbance of MEAV (Mean \pm SD) \\
\hline $5 \mu \mathrm{g} / \mathrm{ml}$ & $0.18 \pm 0.03$ & $0.13 \pm 0.02$ \\
$10 \mu \mathrm{g} / \mathrm{ml}$ & $0.35 \pm 0.04$ & $0.27 \pm 0.03$ \\
$15 \mu \mathrm{g} / \mathrm{ml}$ & $0.53 \pm 0.05$ & $0.42 \pm 0.03$ \\
$30 \mu \mathrm{g} / \mathrm{ml}$ & $0.71 \pm 0.01$ & $0.62 \pm 0.05$ \\
$60 \mu \mathrm{g} / \mathrm{ml}$ & $0.85 \pm 0.05$ & $0.79 \pm 0.02$ \\
$100 \mu \mathrm{g} / \mathrm{ml}$ & $1.04 \pm 0.05$ & $0.95 \pm 0.05$ \\
\hline
\end{tabular}

( $400 \mathrm{mg} / \mathrm{kg}$ b. wt.) was moderate at the maximum time of the studies $(60 \mathrm{~min})$ at a value of $3.40 \pm 0.300$ in comparison with the activity of the standard drug indomethacin (10 $\mathrm{mg} / \mathrm{kg}$ body wt.) at $5.134 \pm 0.351$. Whereas, the lower dose at $200 \mathrm{mg} / \mathrm{kg} \mathrm{b}$. wt. was resulted least activity and showed the value $2.90 \pm 0.200$ (Table 5). Therefore, the intensity and the period of analgesic effect of MEAV were considered as dose dependent.

\section{Discussion}

In this study, the presence of saponins, glycosides, flavanoids, protein, triterpenoids were reported in the phytochemicals screening. The phytochemicals in most of the plants extract had diverse biological properties, such as analgesic, anti-carcinogenic, anti-inflammatory and antioxidant activities and their presence also ensured the medicinal potential and their therapeutic activities [35]. The previous literature also supported that the analysis of Artemisia species showed the presence of coumarin, saponins, glycosides, flavanoids, proteins, and triterpenoids [6]. There was also report that terpenoids is one of the most commonly found metabolites in most of the genus of Artemisia [9]. A similar phytochemical study in the aerial parts of Artemisia vulgaris had shown the presence of certain secondary metabolites like amino acid, carbohydrate, flavonoids, phenolic compounds, phytosterol, proteins, saponins and tannin [36].

Subsequently, A. vulgaris leaves extract has shown a reasonable potential of antioxidants activity with the percentage inhibition of $68.06 \%$ at $60 \mu \mathrm{g} / \mathrm{ml}$ concentration and ferric reducing power of $0.95 \pm 0.05$ at100 $\mu \mathrm{g} /$ ml. The resulted antioxidant properties might be considered due to the high contents of flavonoid compound which act as a scavenging agents for different oxidizing species such as hydroxyl radical and super oxide anion (O2-•) [1]. Iqbal et al. reported that the methanol extract of $A$. annua leaves showed the higher scavenging activities and reducing power comparatively with the other solvents. His finding further resulted that the constituent having antioxidant properties were extracted efficiently with the polar solvents in the extract of Artemisia species [7]. The $\mathrm{IC}_{50}$ value interprets the results of the DPPH assay, which defies the minimum concentration of methanol extract, requires to scavenging $50 \%$ of free radicals [37]. The scavenging properties may be due to chelation and transfer of electron or the ability of hydroxyl groups to donate the hydrogen to free radical [38, 39]; similarly the present finding was showed resemblance with these previous studies. Hence it can say that the tested extract have ability to transform the ferric ion $(\mathrm{Fe} 3+)$ to ferrous ion $(\mathrm{Fe} 2+)$ as reducing power with the increase of concentration of the extract.

In addition to in-vivo study, the methanol extract of A. vulgaris showed a noteworthy analgesic effect in the acetic acid-induced writhing test and tail immersion activity. And it was known that induced acetic acid to observe the abdominal constriction and tail immersion to see the deflexion of the tail were the suitable technique to assess the centrally acting analgesics activity [40]. Since, the pain that causes by administering of acetic acid is due to the endogenous substances such as serotonin histamine,

Table 4 Effect of methanol extract of A. vulgaris leaves extracts on acetic acid-induced writhing behavior in mice

\begin{tabular}{lllll}
\hline Groups & Treatment & Dose $(\mathbf{m g} / \mathbf{k g}$ b.wt.) & No.of Writhes in $\mathbf{3 0}$ mins (mean \pm sem) & Inhibition \% \\
\hline Control & Normal Saline & $\ldots \ldots$ & $42.67 \pm 3.756$ & $\ldots . .$. \\
Std. Drugs & Indomethacin & 10 & $18.33 \pm 0.882^{*}$ & 56.87 \\
Test 1 & MEAV & 200 & $39.00 \pm 1.155$ & 8.60 \\
Test 2 & MEAV & 400 & $29.00 \pm 1.155^{*}$ & 32.03 \\
& One way ANOVA & F value & 27.213 \\
& & $P$ value & $<0.0001$
\end{tabular}

Each value is the mean \pm SEM for 6 mice, ${ }^{*} P \leq 0.05$, compared with control. Data were analyzed by using One-way ANOVA followed by Duncan's multiple comparison tests 
Table 5 Protective effect of methanol extract of A. vulgaris leaves extract on tail withdrawal reflexes induced by tail immersion method in mice

\begin{tabular}{|c|c|c|c|c|c|c|c|}
\hline \multirow[t]{2}{*}{ Groups } & \multirow[t]{2}{*}{ Treatment } & \multirow{2}{*}{$\begin{array}{l}\text { Dose (mg/ } \\
\text { kg b. wt) }\end{array}$} & \multicolumn{5}{|c|}{ Reaction time in seconds at time (minutes) (mean \pm sem) } \\
\hline & & & basal time & 10 & 15 & 30 & 60 \\
\hline Control & Normal saline & $\ldots .$. & $1.10 \pm 0.577$ & $1.40 \pm 0.115$ & $1.60 \pm 0.264$ & $1.834 \pm 0.230$ & $2.734 \pm 0.757$ \\
\hline Std. Drugs & Indomethacin & 10 & $1.47 \pm 0.272$ & $2.534 \pm 145^{*}$ & $3.334 \pm 0.230^{*}$ & $4.10 \pm 0.200^{*}$ & $5.134 \pm 0.351^{*}$ \\
\hline Test 1 & MEAV & 200 & $1.067 \pm 0.881$ & $1.50 \pm 0.300$ & $1.734 \pm 0.152$ & $2.367 \pm 0.208^{*}$ & $2.90 \pm 0.200^{*}$ \\
\hline Test 2 & MEAV & 400 & $1.234 \pm 0.120$ & $2.067 \pm 0.208^{*}$ & $2.834 \pm 0.251^{*}$ & $3.034 \pm 0.152^{*}$ & $3.40 \pm 0.300^{*}$ \\
\hline \multirow{2}{*}{\multicolumn{2}{|c|}{ One way ANOVA }} & $F$ value & 1.319 & 14.136 & 40.778 & 71.556 & 17.509 \\
\hline & & $P$ value & 0.334 & $<0.001$ & $<0.0001$ & $<0.0001$ & $<0.001$ \\
\hline
\end{tabular}

Each value was the mean \pm SEM for 6 mice, ${ }^{*} \mathrm{P} \leq 0.05$, compared with control. Data were analyzed by using One-way ANOVA followed by Duncan's multiple comparison tests

prostaglandins (PGs), bradykinins and substance $\mathrm{P}$ at the nerve ending [41]. Thus, the analgesic activities of the extract may be presence of saponins and that too pharmacological history of these compounds in analgesic and antispasmodic activity [42].

Moreover, the finding of the present study had shown $8.60 \%$ and $32.03 \%$ at 200 and $400 \mathrm{mg} / \mathrm{kg}$ b.wt. in acetic induced writhing effect and in tail withdrawal reflexes time with $3.40 \pm 0.300$ and $2.90 \pm 0.200$ at the same dose. Tatiya et al. reported that ethyl acetate extract of $B$. retusa inhibit the writhing effect induced by the acetic acid at dose dependent with strong inhibition of $65.62 \%$ at $400 \mathrm{mg} / \mathrm{kg}$ and suggested that the analgesic effect of the extract was due to the inhibition of the synthesis of arachidonic acid metabolite [43]. Recently, Bhattacharjee et al. evaluated the analgesic activity of methanolic extract of Lathyrus sativus seeds at the dose 200 and 300 $\mathrm{mg} / \mathrm{kg} \mathrm{b}$. wt. and found a very significant inhibition $(87.09 \%$ and $80.65 \%)$ of writhes induced by acetic acid in mice in comparison to indomethacin (70.97\%) [44]. Consequently, a similar kind of the finding was made by the Islam et al. with extract of Campsis radicans, where he took the doses of 200 and $400 \mathrm{mg} / \mathrm{kg}$ b.wt., and proved high analgesic activity [45]. Overall, the finding of present study was also fully supported by these above previous researches.

\section{Conclusion}

According to the present finding, the studies conclude that methanol extract of Artemisia vulgaris has good antioxidant property and it could be attributed to the presence of flavonoids, triterpenoids, saponin, glycosides and proteins. The constituents of this plant can be used as an accessible source of natural antioxidants in cosmetics, food supplements as well as in pharmaceuticals. The estimated results also provide useful information for using A. vulguris as a source of analgesic drugs. A further study is required to find out the novel bioactive compound of $A$. vulgaris which can lead more effective in various biological activities.

\section{Abbreviations}

g: gram; CPCSEA: The Committee for the Purpose of Control and Supervision of Experiments on Animals; FeCl3: Ferric chloride; $\mathrm{H}_{2} \mathrm{SO}_{4}$ : Sulphuric acid; $\mathrm{HNO}_{3}$ : Nitric acid; DPPH: 2,2-diphenyl-1-picrylhydrazyl; MEAV: methanolic extract of Artemisia vulgaris; OECD: Organization for Economic Co-operation and Development; ANOVA: Analysis of variance

\section{Acknowledgements}

The authors are thankful to Department of Horticulture, Aromatic and Medicinal Plants, Mizoram University, Aizawl and Department of Zoology, Mizoram University, Aizawl for providing necessary Laboratory and Animal house facilities during compilation of the present work.

\section{Authors' contributions}

NMT, JT and AK* carried out the collection of plant. NMT and JT conducted the extraction process and the research work. NMT wrote the manuscript. NMT and $\mathrm{AK}^{*}$ design the study, statistical analysis and data interpretation of data. NMT and $\mathrm{AK}^{*}$ revised the manuscript. All authors read and approved the final manuscript.

\section{Funding}

This research work was carried out by the author in the partial fulfillment of the requirements for the dissertation of Master degree in Aromatics and Medicinal Plants. Authors did not receive any funding for conducting the research work.

\section{Availability of data and materials}

Not applicable.

\section{Ethics approval and consent to participate}

This study was approved by ethical research committee of Mizoram University, Aizawl, Mizoram, India. (Approval No. MZU-IAEC/2018/10).

\section{Consent for publication}

Not applicable.

\section{Competing interests}

The authors declare that they have no competing interests.

Received: 26 June 2020 Accepted: 3 November 2020

Published online: 09 November 2020

\section{References}

1. Pandey BP, Thapa R, Upreti A. Chemical composition, antioxidant and antibacterial activities of essential oil and methanol extract of Artemisia vulgaris and Gaultheria fragrantissima collected from Nepal. Asian Pac J Trop Med. 2017;10(10):952-9. https://doi.org/10.1016/j.apjtm.2017.09.005.

2. Ekor M. The growing use of herbal medicines: issues relating to adverse reactions and challenges in monitoring safety. Front Pharmacol. 2014;4:177. https://doi.org/10.3389/fphar.2013.00177.

3. Kumar A, Gupta R, Mishra RK, Shukla AC, Dikshit A. Pharmaco-phylogenetic investigation of Micromeria biflora Benth and Citrus reticulata Blanco. Nat Acad Sci Lett. 2012;35(4):253-7. https://doi.org/10.1007/s40009-012-0029-7. 
4. Abad MJ, Bedoya LM, Apaza L, Bermejo P. The Artemisia L. genus: a review of bioactive essential oils. Molecules. 2012;17(3):2542-66. https://doi.org/10. 3390/molecules17032542.

5. Tang HQ, Hu J, Yang L, Tan RX. Terpenoids and flavonoids from Artemisia species. Planta Med. 2000;66(04):391-3. https://doi.org/10.1055/s-2000-8538.

6. Wright CW. Artemisia. New York: Taylor \& Francis; 2002

7. Bora KS, Sharma A. The genus Artemisia: a comprehensive review. Pharm Biol. 2011;49(1):101-9. https://doi.org/10.3109/13880209.2010.497815.

8. Iqbal S, Younas U, Chan KW, Zia-Ul-Haq M, Ismail M. Chemical composition of Artemisia annua $\mathrm{L}$. leaves and antioxidant potential of extracts as a function of extraction solvents. Molecules. 2012;17(5):6020-32. https://doi. org/10.3390/molecules17056020.

9. Tanaya G, Prasenjit M, Mitra PK. Effect of leaves of Artemisia vulgaris L. on growth of rats. Int J Herb Med. 2013;1(2):30-4

10. Erel ŞB, Reznicek G, Şenol SG, Yavasoglu NÜK, Konyalioğlu S, Zeybek AU. Antimicrobial and antioxidant properties of Artemisia L. species from western Anatolia. Turk J Biol. 2012;36(1):75-84.

11. Gharachorlou AA, Shamami K. Study on antifungal activity of Artemisia L. extract in compared with tryptophan against trichophyton mentagrophytes. Bull Env Pharmacol Life Sci. 2013;3(1):37-41.

12. Song Y, Desta KT, Kim GS, Lee SJ, Lee WS, Kim YH, Jin JS, Abd El-Aty AM, Shin HC, Shim JH, Shin SC. Polyphenolic profile and antioxidant effects of various parts of Artemisia annua L. Biomed Chromatogr. 2016;30(4):588-95. https://doi.org/10.1002/bmc.3587.

13. Singh BR, Singh V, Singh RK, Toppo S, Haque N, Ebibeni N. Antimicrobial effect of Artemisia vulgaris essential oil. Nat Prod. 2011;7:5-12.

14. Rai PD, Paudel N, Shakya SR. Cytological effects of leaf extract of Artemisia vulgaris L. on Meristematic cells of Allium cepa L. Our Nature. 2012;10(1): 242-8. https://doi.org/10.3126/on.v10i1.7787.

15. Ben-Nasr H, Abderrahim MAB, Salama M, Ksouda K, Zeghal KM. Potential phytotherapy use of Artemisia plants: insight for anti-hypertension. J Appl Pharm Sci. 2013;3(5):120-5.

16. Maham M, Moslemzadeh $H$, Jalilzadeh-Amin G. Antinociceptive effect of the essential oil of tarragon (Artemisia dracunculus). Pharm Biol. 2014;52(2):20812. https://doi.org/10.3109/13880209.2013.824007.

17. Ashok PK, Upadhyaya K. Evaluation of analgesic and anti-inflammatory activities of aerial parts of Artemisia vulgaris L. in experimental animal models. JBAPN. 2013;3(1):101-5. https://doi.org/10.1080/22311866.2013. 782761

18. Becker DE, Phero JC. Drug therapy in dental practice: nonopioid and opioid analgesics. Anesth Prog. 2005;52(4):140-9.

19. Calixto JB, Beirith A, Ferreira J, Santos AR, Filho VC, Yunes RA. Naturally occurring antinociceptive substances from plants. Phytother Res. 2000;14(6): 401-18.

20. Ghasemzadeh A, Ghasemzadeh N. Flavonoids and phenolic acids: role and biochemical activity in plants and human. J Med Plant Res. 2011;5(31):6697-703.

21. Godghate A, Sawant R, Sutar A. Phytochemical analysis of ethanolic extract of roots of carrissa carandus Linn. Rasayan J Chem. 2012;5(4):456-9.

22. Kumar A, Jha KK, Kumar D, Agrawal A, Gupta A. Preliminary phytochemical analysis of leaf and bark (mixture) extract of Ficus infectoria plant. Pharm Innov. 2012;1(5):71-6.

23. Auwal MS, Saka S, Mairiga IA, Sanda KA, Shuaibu A, Ibrahim A. Preliminary phytochemical and elemental analysis of aqueous and fractionated pod extracts of Acacia nilotica (thorn mimosa). Vet Res Forum. 2014;5(2):95-100.

24. Gul R, Jan SU, Faridullah S, Sherani S, Jahan N. Preliminary phytochemica screening, quantitative analysis of alkaloids, and antioxidant activity of crude plant extracts from Ephedra intermedia indigenous to Balochistan. Sci World J. 2017. https://doi.org/10.1155/2017/5873648.

25. Blois MS. Antioxidant determinations by the use of a stable free radical. Nature. 1958;181:1199-200. https://doi.org/10.1038/1811199a0.

26. Olugbami JO, Gbadegesin MA, Odunola OA. In vitro free radical scavenging and antioxidant properties of ethanol extract of Terminalia glaucescens. Pharm Res. 2015;7(1):49. https://doi.org/10.4103/0974-8490.147200.

27. Oyaizu M. Studies on products of browning reaction. Jpn J Nutr Diet. 1986; 44(6):307-15. https://doi.org/10.5264/eiyogakuzashi.44.307.

28. Bhalodia NR, Nariya PB, Acharya RN, Shukla VJ. In vitro antioxidant activity of hydro alcoholic extract from the fruit pulp of Cassia fistula Linn. Ayu. 2013; 34(2):209. https://doi.org/10.4103/0974-8520.119684.

29. Committee for the Purpose of Control and Supervision on Experiments on Animals. CPCSEA guidelines for laboratory animal facility. Indian J Pharmacol. 2003;35(4):257-74.
30. No OT. 423: Acute oral toxicity-acute toxic class method. In: OECD guidelines for the testing of chemicals (section 4: health effects); 2001. p. 114.

31. Thangjam NM, Kumar A, Shukla AC, Shukla N, Singh CB. Antifertility studies of Phologacanthus thyrsiflorus Nees: a potential ethno-medicinal plant of north East India. J Indian Bot Soc. 2019;98(3\&4):207-11.

32. Barua CC, Roy JD, Buragohain B, Barua AG, Borah P, Lahkar M. Analgesic and anti-nociceptive activity of hydroethanolic extract of Drymaria cordata Willd. Indian J Pharmacol. 2011;43(2):121-5.

33. Suseem SR, Saral M, Reddy N, Gregory M. Evaluation of the analgesic activity of ethyl acetate, methanol and aqueous extracts of Pleurotuseous mushroom. Asian Pac J Trop Med. 2011;4(2):117-20. https://doi.org/10.1016/ S1995-7645(11)60049-7.

34. Yemitan OK, Adeyemi OO. Mechanistic assessment of the analgesic, antiinflammatory and antipyretic actions of Dalbergia saxatilis in animal models. Pharm Biol. 2017;55(1):898-905. https://doi.org/10.1080/13880209.2017. 1283706.

35. Majid M, Khan MR, Shah NA, Haq IU, Farooq MA, Ullah S, Sharif A, Zahra Z, Younis T, Sajid M. Studies on phytochemical, antioxidant, anti-inflammatory and analgesic activities of Euphorbia dracunculoides. BMC Complem Altern M. 2015;15(1):349. https://doi.org/10.1186/s12906-015-0868-0.

36. Ashok PK, Kumud U. Preliminary phytochemical screening and physicochemical parameters of aerial parts of Artemisia vulgaris. Int J Res Ayurveda Pharm. 2010;1(1):206-11.

37. Mallick M, Bose A, Mukhi S. Comparative evaluation of the antioxidant activity of some commonly used spices. Int J PharmTech Res. 2016;9(1):1-8.

38. Alam I, Forid S, Roney M, Aluwi FFM, Huq M. Antioxidant and antibacterial activity of Ipomoea mauritiana Jacq.: a traditionally used medicinal plant in Bangladesh. Clin Phytosci. 2020;6(1):1-7. https://doi.org/10.1186/s40816-02000185-w.

39. Gülçin I, Huyut Z, Elmastaş M, Aboul-Enein HY. Radical scavenging and antioxidant activity of tannic acid. Arab J Chem. 2010;3(1):43-53. https://doi. org/10.1016/j.arabjc.2009.12.008.

40. Bachhav RS, Gulecha VS, Upasani C. Analgesic and anti-inflammatory activity of Argyreia speciosa root. Indian J Pharm. 2009:41(4):158.

41. Wazis C, Timothy S, Yesufu H, Mashi J. Phytochemical screening and analgesic effect of ethanol leaf extract of Psidium guajava L. J Pharm Sci Innov. 2015;4:304-7.

42. Abdul-Awal SM, Nazmir S, Nasrin S, Nurunnabi TR, Uddin SJ. Evaluation of pharmacological activity of Hibiscus tiliaceus. Springer Plus. 2016;5(1):1209. https://doi.org/10.1186/2Fs40064-016-2891-0.

43. Tatiya AU, Saluja AK, Kalaskar MG, Surana SJ, Patil PH. Evaluation of analgesic and anti-inflammatory activity of Bridelia retusa (Spreng) bark. J Tradit Complement Med. 2017;7(4):441-51. https://doi.org/10.1016/2Fj.jtcme.2016. 12.009 .

44. Bhattacharjee S, Waqar A, Barua K, Das A, Bhowmik S, Debi SR. Phytochemical and pharmacological evaluation of methanolic extract of Lathyrus sativus L. seeds. Clin Phytosci. 2018;4(1):20. https://doi.org/10.1186/ s40816-018-0081-z.

45. Islam M, Jannat T, Kuddus MR, Rashid MA, Haque MR. In vitro and in vivo evaluation of pharmacological potentials of Campsis radicans L. Clin Phytosci. 2019;5(1):42. https://doi.org/10.1186/s40816-019-0144-9.

\section{Publisher's Note}

Springer Nature remains neutral with regard to jurisdictional claims in published maps and institutional affiliations. 